\title{
Development of Learning Management Models for Enhancing System Approach Thinking Ability and Calculus Achievement of 12 Great Students
}

\author{
Payeakorn Beakratok ${ }^{1}$, Pornchai Jedaman ${ }^{2}$ and Benjapuk Jongmuanwai ${ }^{3}$
}

\begin{abstract}
A specific purposes to development of learning management models for enhancing system approach thinking ability and calculus achievement of 12 great students. The instruments employed were learning management model, lesson plans, achievement test, system approach thinking ability test, calculus achievement test, and satisfaction questionnaire. Learning management models to consisted of four components as; a) syntax which includes six phases of (1) presentation of problems, (2) development of thinking, (3) select strategies for problem, (4) exchange of thought, (5) group to learning, (6) summary, b) social system, c) principles of reaction, d) support system. The efficiency of learning management models on calculus contents to efficient combining process and outcome aspects at all the scoring of 84.07/ 86.36. System approach thinking ability of the students on after learning management, and calculus achievement to higher than before were statistically significant difference at $\mathbf{. 0 5}$. level. Students' satisfaction of high levels, that to discussion and implementation.
\end{abstract}

Keywords:- Learning Management Models, System Approach Thinking Ability, Calculus Achievement.

\section{INTRODUCTION}

The Revised National Education Plan (B.E. 25522559) is a master plan under the National Education of the well-round, balanced human development, Promoting Thai society to be the moral, knowledge, learning society, Developing social environment for Thai citizen and society for moral and knowledge-based society. Also, National strategic frameworks for 20 Years (A.C., 2018-2037), Thailand aims to stable-prosperous- sustainable economy under the development of the sufficiency Economy. The frameworks contribute to the development of happiness for Thais' and respond to achieve the national interest and Thailand was developed country. The goals for improve the quality of life, social security, equality fairness. [1] The education goals to the quality development and efficiency, educational and learning opportunities, include Thais' attribute in Thailand 4.0 to accord the participation support for all sectors. [2] An importance for science educational driven to concrete actions of the impacts to output and outcome, and goal, vision achieves were strategic 1: fairness create of societies, strategic 2: human resource development to the lifetime learning societies for sustainable, strategic 3: create of the balances and stabilities, strategic 4: create of knowledge base economics and environmental, strategic 5: create of economics linking between the countries, stability of regional counties, strategic 6: natural resources and environments management for sustainable.

A learning mathematics is learning logically and effectively, systems and methods, analytical thinking processes from problems in various situations to great importance for the development of students to be qualified and completely human, including can be adapted for effective change of able to live a normal life in a globalized society. [3] A based on building critical thinking and problem solving are the strategies for learning and building on the basis of humanity, capacities for thinking and performance, creative work and training students to think critically and reason in a systematic manner, it is the learning management for students to develop desirable attributes and systematic thinking skills as well as creativity, learning management potential, communication skills and the use of technology, adjusting ways of thinking and working methods to suit the situation into the intelligence effectively. learning management in calculus subjects for the students to be able as applying the knowledge to problem solving as well as have a good attitude, the conceptual of effective learning. [4] By the learning management model a very important role in the process of development learning efficiency for students from the collection of information content that helps learners have extensive knowledge and understanding, can continue a learning of make the students to the most effective learning ability. This research to development of learning management models for enhancing system approach thinking ability and calculus achievement of 12 great students into the objectives this study were followed;

$>$ To development of learning management models for enhancing system approach thinking ability and calculus achievement of 12 great students.

$>$ To evaluation to efficiency of learning management models for enhancing system approach thinking ability and calculus achievement of 12 great students.

$>$ To compare of system approach thinking ability and calculus achievement before and after being taught by learning management model of 12 great students.

$>$ To investigate satisfaction of 12 great students towards learning management model. 


\section{THEORY CONCEPTUAL}

\section{$>$ Revised National Education Plan (B.E. 2552-2559):-}

The Revised National Education Plan (B.E. 25522559 ) is a master plan under the National Education. Emphasizes the application of sufficiency philosophy introduced by H.M. King Bhumibol Adulyadej. The Sufficiency Economy Philosophy focuses the people as center of country development. Objectives and policies of Sufficiency Economy [1] are to:

- The well-round, balanced human development. The policies are: developing quality education in every levels and formats; cultivating ethics, moral and values in learners; developing the twelve core values of Thai people found in Thai university students. The twelve values consist of the following attributes; (1) upholding the nation, the religions and the monarchy, (2) being honest, sacrificial and patient with positive attitude for the common good of the public, (3) being grateful to the parents, guardians and teachers, 4) seeking knowledge and education directly and indirectly, (5) treasuring the precious Thai's tradition, (6) maintaining moral, integrity, well-wishes upon others as well as being generous and sharing, (7) understanding, learning the true essence of democratic ideals with His Majesty the King as head of state, (8) maintaining discipline, respectful of laws and the elderly and seniority, (9) being conscious and mindful of action in line with His Majesty's the King's statements, (10) practicing the philosophy of Sufficiency Economy of His Majesty the King. Saving money for time of need. Being moderate with surplus used for sharing or expansion of business while having good immunity, (11) maintaining both physical and mental health and unyielding to the dark force or desires, having sense of shame over guilt and sins in accordance with the religious principles, (12) putting the public and national interest before personal interest. Education should be promoted to all levels and groups of learners including poor, special abilities, disadvantage, disabilities students. Thai citizen should be promoted to serve the goal of Thailand within the high competitiveness era. The educational quality assurance system must be set to internal and external school levels. The teacher preparation system should be redesign to produce more quality teachers and educational personnel.

- Promoting Thai society to be the moral, knowledge, learning society. Thailand aims to promote education and training of religion and social institutes and local wisdom networks. Education should be promoted in all levels and types including normal, informal and nonformal education. Education in Thailand should promote people playing sports for improving physical and psychological strengths. Thailand must promote research and development for building bodies of knowledge, innovation, and intellectual properties. The management system and mechanics must be developed with the aim of highest utilization of knowledge from research.
- Developing social environment for Thai citizen and society for moral and knowledge-based society. Thailand should utilize information technology in developing quality of education and enhancing equality in education and life-long learning.

Thailand must develop effective education management by decentralizing education and educational management to schools, education service area offices and local agencies. All sectors in Thai society should be invited to participate in education management and supporting educational resources and investment. Education should aim to promote internalization of education of ASEAN community and enhance the competitive ability with others and corporate with world citizen with happiness, dependency and interdependency. The strategic plan aims to promote the quality of people to be able to think, do, solve problem and think reasonably. Also, Thai's people should be responsible, discipline and fair and have moral and ethics. They should be able to utilize, blend and balance information technology and local wisdom to enhance their quality of lives. Thai society should aim to knowledge and competency-based society.

\section{System Thinking Process Throughout Calculus Achievement:-}

The system thinking process is another form of human thinking used to look at the problems, by the problem will be considered in three levels of events, patterns of behavior, and systems structure, when phenomena, situations, and problems arise, an understanding of the situation will be considered to that the cause of the situation. What factors are there? Then consider whether the causal factors are correlated. How they are linked in cause and effect ? To considered a systematic thinking process. [5] Which is to explain and understand the power and the interrelationships between the factors that lead to the shift in system behavior in the desired direction. The system thinking process as the relationship of thinking in a collective way. [6] The knowledge based society and life learning organization from strengthening the discipline to the students including personal mastery, mental models, team learning, shared vision and systems thinking. The learning organization it is an organization where members develop and expand their capabilities for the creation of work and achieving work goals, problems solving and creating new innovations continuously. [7] Especially the systematic thinking skills are the bases, because the system thinking process of the something that supports and is consistent with the scientific method in cause and effect, including behavioral science. the focus of system thinking process there are the feedback of experiential learning and learning from other team members, which this interaction will depend on all parts that make up the system of the learning organization. [8] Therefore, the system thinking process to requires a system of action. And continued acceptance and re-examination In the essence of reality to affective the efficiency in the system thinking process that is relevant and related to the learning achievement of the students. [9] The development of a system thinking process will promote learning that is conducive to increasing the academic achievement, and 
great result in moral development, desirable ethics and values into behavior of students directly as consistent across all forms of learning management aimed to improve the quality of thinking. [10] By building the skills of thinking methods from the use of different styles of learning management will be an enable learning that to development of the students' thinking to look holistic. This study to the instruments to development of learning management models as syntax, b) social system, c) principles of reaction, d) support system, the evaluation to efficiency of learning management models, compare to system approach thinking ability and calculus achievement before and after being taught by learning management model, and investigate satisfaction of the students towards learning management model.

\section{THE METHODS}

D Data Methods:- The results were to action research throughout brainstorming, implementing of the learning management and evaluation and survey into study to development of learning management models for enhancing system approach thinking ability and calculus achievement of 12 great students to the data methods.

> Samples Methods:-The results samples methods that will be used in this study with the key informants of 9 teachers expert to brainstorming, and 81 students in 12 great of Chumpharesuksa school, Thailand for implementing of the learning management on calculus contents. The participants they all were by purposive sampling of the samples method.

> Collection Methods:- Respondents were asked to respond of collection methods into the instrument into development of learning management models as syntax, social system, principles of reaction, support system came from a documentary and brainstorming with the teachers expert, bring learning management models as implementing of the learning management with 12 great students to evaluation to efficiency of learning management on calculus contents including limits and continuity of the function, derivative of the function, applications of the derivative, integration, techniques of integration, definite integral and the application in according to the specified criteria of $80 / 80$, compare to system approach thinking ability by a measure that covers four cognitive abilities of determine the problem, analyze the sub-factors, find the relationship between the sub-factors, synthesize the problem cycle, and calculus achievement by the test achievement, before and after being taught of learning management as type $4^{\text {th }}$ options, and investigate satisfaction of the students towards learning management model by questionnaire of 5 scales to the data.
Inquiry Methods:- An inquiry methods into the collections on instrument study to development of learning management models for enhancing system approach thinking ability and calculus achievement of 12 great students in data analysis was analyzed by descriptive statistically analysis including percentage, mean, standard deviation, and compare to the difference value by t-test.

\section{RESEARCH FINDINGS}

The development of learning management models for enhancing system approach thinking ability and calculus achievement of 12 great students of research findings were followed:

A. Learning management models for enhancing system approach thinking ability and calculus achievement of 12 great students:-

$>$ Process of organizing activities (Syntax):-

- Step 1:- Presents the situation; presenting problematic situations that cause conflicts of problems in order to motivate students of thinking.

- Step 2:- Develop a way of thinking; encouraging students to search for information to answer intellectual conflicts with reasonable and effective answers. And is the answer to the problem with information as used for writing a mind map.

- Step 3:- Consider the problem; encouraging students to experience by practicing thinking and self-learning in order to be able to identify and identify cause factors and write the relationships between factors to be able to design and write a circuit causing problems.

- Step 4:- Discussion and exchange of knowledge; encouraging students to talk and learn with their peers, also, that each person have the opportunity to present their ideas to friends and help, commenting to find a conclusion which is the resolution of the group.

- Step 5:- Learning group works; encouraging students to present their ideas to a large group meeting, each sub-group must send a representative to report their conclusions, and small group thinking results to large groups so that each person has the opportunity to see the results of other people's thinking, which helps to create dimension. And an increasingly exotic perspective.

- Step 6:- Conclusion; Discussion and summarizing both the content and the concept derived from the thinking and the grades that students have discovered, it is the right thing to be sure in the future, students will be able to learn by themselves. 


\section{Social System:-}

Learning management whereby teachers must prepare sufficient and ready situations and questions, as well as problem-solving strategies that will be used for students to practice their skills, there are creating experiences for students, where students' learning activities must be organized together in a group where each individual has a responsibility, interacting well with each other for achieve the desired goal of learning, having a good dependence on each other. By social skills and group work processes to enable all members to cooperate, contribute to And have the opportunity to express their full knowledge, and every talents.

\section{Principles of Reaction:-}

During the learning management activities, teachers must try to foster good interaction with each other within the group, and encourage all members to express their opinions, speak and dare to do things that will benefit group members and friends, train students to independently present ideas to members.

\section{Support System:-}

The teachers must prepare the questions and provide teaching materials ready and sufficient, creating a good learning environment with students, and between students and peers within groups and between groups as well as building good relationships, fostering a wide range of thinking with thinking skills related to problem solving, allow students to exchange and learn independently, with teachers to facilitate and help students.

\section{B. The efficiency of learning management models in according to the specified criteria of 80/80:-}

Efficiency of learning management models on calculus contents including limits and continuity of the function, derivative of the function, applications of the derivative, integration, techniques of integration, definite integral and the application in according to the specified criteria of $80 / 80$ to shown on table 1 .

\begin{tabular}{|c|c|c|c|}
\hline \multirow[t]{2}{*}{ Calculus contents } & \multicolumn{2}{|c|}{ Scoring } & \multirow{2}{*}{$\begin{array}{c}\text { Efficiency to } \\
\text { criteria of } 80 / 80\end{array}$} \\
\hline & Process & Outcome & \\
\hline 1. Limits and continuity of the function & 83.50 & 85.65 & $83.50 / 85.65$ \\
\hline 2. Derivative of the function & 82.75 & 85.32 & $82.75 / 85.32$ \\
\hline 3. Applications of the derivative & 84.29 & 85.50 & $84.29 / 85.50$ \\
\hline 4. Integration & 83.25 & 86.75 & $83.25 / 86.75$ \\
\hline 5. Techniques of integration & 85.28 & 86.50 & $85.28 / 86.50$ \\
\hline 6. Definite integral and the application & 85.35 & 88.45 & $85.35 / 88.45$ \\
\hline Totals & 84.07 & 86.36 & $84.07 / 86.36$ \\
\hline
\end{tabular}

Table 1:- Scoring efficiency on calculus contents in according to the specified criteria of $80 / 80$

The efficiency of learning management models in according to the specified criteria of $80 / 80$ on calculus contents including limits and continuity of the function, derivative of the function, applications of the derivative, integration, techniques of integration, definite integral and the application to efficient combining process and outcome aspects at all the scoring of 84.07/ 86.36. which to highest to the specified criteria of $80 / 80$.

\section{System approach thinking ability and calculus achievement:-}

The system approach thinking ability of determine the problem, analyze the sub-factors, find the relationship between the sub-factors, synthesize the problem cycle , from compare between before and after being taught by learning management model, by t-test to shown on table 2 .

\begin{tabular}{|c|c|c|c|c|c|c|}
\hline $\begin{array}{c}\text { System approach thinking } \\
\text { ability }\end{array}$ & $\mathrm{N}$ & Full Scoring & $\overline{\mathrm{X}}$ & S.D. & $\mathbf{t}$ & $\mathrm{p}$ \\
\hline $\begin{array}{c}\text {-Before learning management } \\
\text {-After learning management }\end{array}$ & 81 & 20 & 14.03 & 0.95 & $16.56^{*}$ & .000 \\
\hline
\end{tabular}

$* \mathrm{p}<.05$.

Table 2:- Scoring system approach thinking ability between before and after, by t-test

The system approach thinking ability of determine the problem, analyze the sub-factors, find the relationship between the sub-factors, synthesize the problem cycle, from compare between before and after being taught by learning management model, by t-test on after learning management to higher than before were statistically significant difference level at .05. 
Calculus achievement from compare between before and after being taught by learning management model, by t-test to shown on table 3 .

\begin{tabular}{|c|c|c|c|c|c|c|}
\hline $\begin{array}{c}\text { System approach thinking } \\
\text { ability }\end{array}$ & $\mathrm{N}$ & Full Scoring & $\overline{\mathrm{X}}$ & S.D. & $\mathbf{t}$ & $\mathrm{p}$ \\
\hline $\begin{array}{c}\text {-Before learning } \\
\text { management }\end{array}$ & 81 & 40 & 2.92 & 0.73 & $13.30^{*}$ & .000 \\
-After learning management & 81 & 40 & 3.25 & 0.67 & & \\
\hline
\end{tabular}

$* \mathrm{p}<.05$.

Table 3:- Scoring calculus achievement between before and after, by t-test

Calculus achievement, from compare between before and after being taught by learning management model, by t-test on after learning management to higher than before were statistically significant difference level at .05.

D. Satisfaction of students towards learning management model:-

Satisfaction levels of students towards learning management model on 3aspacts of teacher, learning management activities, measure and evaluation to shown on table 4.

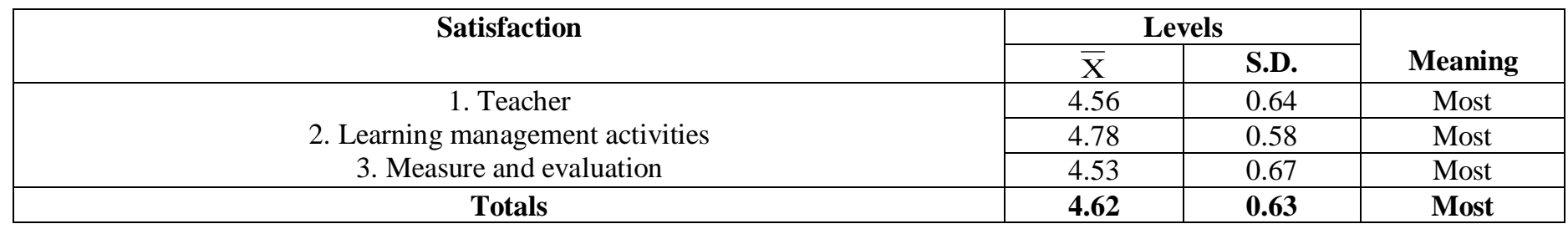

Table 4:- Mean and standard deviation of satisfaction levels

Satisfaction of students towards learning management model at level of high levels $(\bar{X}=4.62$, S.D. $=0.63)$. The highest of learning management activities $(\bar{X}=4.78$, S.D. $=$ $0.58)$, second of teacher $(\bar{X}=4.56$, S.D. $=0.64)$, third of measure and evaluation $(\bar{X}=4.53$, S.D. $=0.67)$, by learning management activities to highest of satisfaction as students interact and seek information from various learning sources, create a good learning atmosphere, and provide opportunities to exchange and learn together freely, respectively.

\section{DISCUSSIONS}

Learning management models to consisted of four components as; a) syntax which includes six phases of (1) presentation of problems, (2) development of thinking, (3) select strategies for problem, (4) exchange of thought, (5) group to learning, (6) summary, b) social system, c) principles of reaction, d) support system. The efficiency of learning management models on calculus contents to efficient combining process and outcome aspects at all the scoring of 84.07/ 86.36. System approach thinking ability of the students on after learning management, and calculus achievement to higher than before were statistically significant difference at .05. level. Students' satisfaction of high levels. This is because the learning management models to emphasize the ability to solve problems in the management of calculus from the presentation of solutions to problems related to systematic thinking, in which each situation of the problem is arranged to suit various problems and allows students to systematically figure out the root cause of the problem from a given situation. And allow each student and group to express their opinions in a systematic manner. Where the students can learn and solve problems as resulting in a systematic thinking process. Nasrudin, H., \& Azizah, U., to said that conducting learning activities, where students cooperate and think actively from learning activities aimed at helping students support and work together as a team, will result in students having the opportunity to express their thoughts fully. Myers, B. E., \& Dyer, J. E., a setting appropriate procedures for activities will make the learning management proceed well. By giving students the freedom to participate in activities according to specific procedures and to have a variety of activities. Wilawan PhoThong, the keeping students interested all the time, by organizing activities at each step there is a sequence of activities that are continually and have distinct characteristics that need to be developed at each step. Learning management models for enhancing system approach thinking ability and calculus achievement in each step of the activities shown to students' system of thinking, for example, in the early stages, students were afraid to think in formulating issues. And when they are motivated to think, the students try to come up with answers by making connections from past experiences that enable them to answer their questions. Simsek, P., \& Kabapinar, F., by the teachers a giving to the students of the opportunity to think and give enough time, to be free and to encourage students to think and analyze for answers, including the students have the opportunity to exchange and learn together of the results in students feeling warm to have friends help each other think. Which the learning activities that each student is enthusiastic and have to fully demonstrated their ability and cooperated in the actions through the groups process, and presenting to makes the work of quality and have the ability to think systematically to efficiently. 


\section{CONCLUSIONS}

Learning management models for enhancing system approach thinking ability and calculus achievement of the students to, 1) process of organizing activities (syntax) have $4^{\text {th }}$ steps to presents the situation, develop a way of thinking, consider the problem, discussion and exchange of knowledge, learning group works, conclusion, discussion and summarizing both the content and the concept derived from the thinking and the grades that students have discovered, it is the right thing to be sure in the future, students will be able to learn by themselves, 2) social system for learning management whereby teachers must prepare sufficient and ready situations and questions, as well as problem-solving strategies that will be used for students to practice their skills, 3) principles of reaction in during the learning management activities, teachers must try to foster good interaction with each other within the group, and 4) support system were the teachers must prepare the questions and provide teaching materials ready and sufficient, creating a good learning environment. The efficiency of learning management models which to highest to the specified criteria. System approach thinking ability and calculus achievement are highest. Satisfaction of students towards learning management model of high levels.

\section{> Implementation:-}

Also, learning activities had an effect that occurred directly on the students to think and solve problems from various situations by themselves, know how to solve problems through thinking skills, working together. in doing activities the students develop social skills, sharing and accepting of others' opinions, leading to efficiency of learning management on calculus contents including limits and continuity of the function, derivative of the function, applications of the derivative, integration, techniques of integration, definite integral and the application, including system approach thinking ability, the students interact and seek information from various learning sources, create a good learning atmosphere, and provide opportunities to exchange and learn together freely, students are doing activities to social skills, sharing and accepting of others' opinions, leading to effectiveness.

\section{REFERENCES}

[1]. Office of the Education Council, Ministry of Education. 2017. Policy and strategy development of education Quality. Bangkok, Thailand: Ministry of Education. The office.

[2]. Jompoun Moungkonvanit. 2019. Organization Management and Education Personnel. Bangkok, Thailand: Julalungkhon University.

[3]. Wilawan PhoThong. 2013. Development of teaching models for developing research psychology for undergraduate students. Educational technology field. Doctor of Education Dissertation, Department of Educational Technology. Chonburi, Thailand: Burapha University.
[4]. Myers, B. E., \& Dyer, J. E. 2006. Effects of investigative laboratory instruction on content knowledge and science process skill achievement across learning styles. Journal of Agricultural Education, 47(4), pp. 52-63.

[5]. Gall, M. D. Joyce, P. G., Walter, R. B. 2007. Educational research: An introduction. New York: Allyn and Bacon.

[6]. McMillan, J. H. 2001. Research in education: A conceptual introduction. New York: Longman.

[7]. Richmond, B. 2000. Toolbox reprint series: The thinking in systems thinking seven essential skills. Waltham Pegasus Communications.

[8]. Woolfolk, A. 2007. Educational psychology (10 ${ }^{\text {th }}$ ed.). Boston: Pearson Education.

[9]. Simsek, P., \& Kabapinar, F. 2010. The effects of inquiry-based learning on elementary students conceptual understanding of matter, sciences process skills and sciences attitudes. Procardia Social and Behavioral Sciences, pp. 1190-1194.

[10]. Nasrudin, H., \& Azizah, U. 2010. Improvement thinking skills and scientific attitude using the implementation of "group- investigation cooperative learning" contextual oriented at acid, base and salt topic in junior high school. Proceedings of the $4^{\text {th }}$ International Conference on Teacher Education; Join Conference UPI \& UPSI Bandung, Indonesia, 2010 (8-10 November), pp. 763-772. 